\title{
FAKTOR - FAKTOR YANG BERHUBUNGAN DENGAN KEPUASAN PEMANFAATAN PENOLONG PERSALINAN PADA IBU BERSALIN DI RUMAH SAKIT GRANDMED LUBUK PAKAM
}

\author{
Basyariah Lubis, ${ }^{1}$ Sri Melda Br Bangun ${ }^{2}$ \\ Institut Kesehatan Medistra \\ Jl. Sudirman No. 38 Lubuk Pakam Kec Lubuk Pakam Kab Deli Serdang \\ Email: basyariahlubis@gmail.com
}

DOI: https://doi.org/10.35451/jkk.v1i2.168

\begin{abstract}
Factors causing high MMR (Maternal Mortality Rate) is highly diverse, among others, is the delay in deciding to seek immediate treatment / assistance, the behavior of people who do not recognize the danger signs and not aware of the existence of complications. Patient satisfaction with the use of birth attendant became one of the main components or most important. Thus, patient satisfaction is one of the goals of improving the quality of health services. In improving the management of service quality complaints / complaint of patients is needed. Until now there are still some complaints (one of which is the lack of attention of the birth attendant) of the patients and families of patients received by the hospital, either directly or indirectly. This type of research is a survey with cross sectional design. Analytical survey method used to determine the factors associated with utilization of satisfaction birth attendants in the Hospital Grand Medistra Lubukpakam The population in this study were women giving birth in hospitals Grand Medistra Lubukpakam with a sample of 73 people. The study was conducted in September $s$ / $d$ in October 2015. The data was obtained using a questionnaire and analyzed using multiple logistic regression test at the level of 95\%. Multivariate analysis with multiple logistic regression test showed that the variables of knowledge has the most impact on satisfaction utilization birth attendants, namely in terms of the value of $B=5.041$ (95\% CI 1.262; 20.129), which means that the knowledge variable has the effect of five (5) times to satisfaction utilization birth attendant. For doctors and midwives Hospital Grand Medistra which helped birth is expected to further improve service to patients with more empathy for patients, providing sufficient time and be more patient to accompany a patient who was in labor, building a good relationship with the patient's family so can further improve the satisfaction in the utilization of birth attendant.
\end{abstract}

Keywords: Patient Satisfaction, Rescue Delivery, Mother Maternity 


\section{Pendahuluan}

Kesehatan adalah Hak Fundamental individu. Sesuatu hal yang sudah dinyatakan World Health Organization (WHO 1948), UndangUndang Dasar 1945 Pasal 28H setiap orang berhak mendapatkan pelayanan kesehatan yang bermutu, dan terjangkau serta memiliki keinginan untuk melakukan tindakan yang akan membuat dirinya memperoleh pelayanan kesehatan yang dibutuhkan untuk dirinya, bangsa memiliki peraturan yang menyatakan bahwa warga boleh mengajukan haknya untuk memiliki pelayanan hidup sehat termasuk juga warga miskin dan warga tak mampu (Depkes RI, 2010). Tujuan program ekspansi (SDGs) menyatakan dalam rancangan pembangunan secara menyeluruh ketimbang rancangan tujuan ekspansi Milenium (MDGs) 2015. Data terakhir (SDKI) menunjukan bahwa capaian indikator Angka Kematian Ibu (AKI) dan Angka Kematian Bayi (AKB) belum mencapai target Millenium Development Goals (MDGs). Indikator Kesehatan SDGs di Indonesia salah satunya adalah mengurangi AKI hingga dibawah 70/100.000 KH, (Rakerkesnas, 2019). Pemanfaatan penolong persalinan terampil di fasilitas kesehatan yang selalu terlambat akan menyebabkan meningkatnya AKI dan neonatal (Endang, 2011). Pemanfaatan fasilitas kesehatan untuk pertolongan persalinan masih belum sesuai dengan target yang ditetapkan pemerintah yakni $90 \%$ ibu melahirkan di tolong oleh dokter atau bidan. Perbandingan ibu melahirkan yang di tolong oleh dokter dan bidan menunjukan adanya peningkatan. Proporsi menunjukan perbedaan yang signifikan dilihat dari tingkat penghasilan ibu bersalin yang ekonominya lebih tinggi dibandingkan dengan ibu bersalin yang penghasilannya lebih rendah. Hal ini menunjukan bahwa tingkat penghasilan seseorang sangat memegang peranan penting dalam penyebaran pelayanan kesehatan yang memadai. (Badan Pusat Statistik), Making Pregnancy Safer (MPS). Dalam pelaksanaan Safe Motherhood terdapat langkah yang di lakukan Making Pregnancy Safer (MPS) dalam memerangi AKI di Indonesia adalah setiap ibu melahirkan ditolong oleh dokter atau bidan, dalam keadaan gawatdarurat ibu bersalin wajib mendapatkan pelayanan yang tepat, dan pasangan usia subur memiliki hak untuk mendapatkan pelayanan preventif untuk kehamilan yang tidak diinginkan. Ada langkah-langkah utama dalam menurunkan kematian ibu. Pertama, memajukan dan meningkatkan kualitas layanan kesehatan bagi ibu dan bayi baru lahir. Kedua, mengefektifkan program listas sektoral dan mitra lainnya. Ketiga, memberdayakan perempuan dalam perilaku hidup bersih dan sehat, Keempat, melibatkan warga untuk menyedikan pelayanan siaga bagi ibu. (Laporan MDGs). Keselamatan ibu dan bayi baru lahir sangat dipengaruhi oleh peranan dokter dan bidan. Rendahnya cakupan ibu bersalin yang ditolong oleh dokter atau bidan dapat dipengaruhi oleh sikap dan perilaku ibu dalam memilih tenaga penolong persalinan. Menurut (Rosenstock,1950) Health Beliefe Model (HBM) dalam (Notoatmodjo, 2007), yang mempengaruhi perilaku sehat atau sakit adalah: Pertama, kepercayaan mengenai kepekaan seseorang terhadap keadaan sakit. Kedua, kepercayaan mengenai komplikasi penyakit. Ketiga, kepercayaan tentang manfaat. Keempat, semboyan tindakan (Cuest), (Notoatmodjo, 2007). Teori HBM memiliki beberapa prinsip pokok yakni 
Pertama, kesigapan seseorang dalam melakukan perubahan perilaku untuk hidup sehat. Kedua, motivasi masyarakat perubahan perilaku; dan ketiga karakter masyarakat untuk melakukan perubahan, interaksi yang berkaitan dengan informasi kesehatan, dan pengalaman yang merubah perilaku (Notoatmodjo, 2007). Berdasarkan survei awal di rumah sakit grand medistra bahwa ibu-ibu yang bersalin mengalami komplikasi sewaktu hamil sehingga mereka memilih prose persalinan dilakukan di rumah sakit dan sebagian banyak di bawa oleh bidanbidan yang melakukan rujukan. Peningkatan proporsi bayi yang dilahirkan dengan bantuan tenaga kesehatan yang profesional adalah langkah yang utama dalam mengurangi resiko kesehatan pada ibu dan anak. Penanganan tenaga kesehatan yang berkualitas dapat mengatasi komplikasi yang dapat menyebabkan kematian ibu dan bayi. Kepuasan pasien terhadap pemanfaatan penolong persalinan menjadi salah satu komponen utama atau yang terpenting. Dengan demikian, kepuasan pemanfaatan penolong persalinan merupakan salah satu tujuan dari meningkatnya kualitas layanan kesehatan. Dapat dibuktikan bahwa pemanfaatan penolong persalinan dan atau masyarakat yang sudah didapatkan kepuasan terhadap layanan kesehatan yang dilaksanakan cenderung mematuhi setiap anjuran yang diberikan dokter atau bidan (Pohan, 2006).

Kondisi tersebut menimbulkan keinginan peneliti untuk meneliti tentang faktor-faktor yang berhubungan dengan kepuasan pemanfaatan penolong persalinan pada ibu bersalin di Rumah Sakit GrandMed Lubuk Pakam.

\section{METODE PENELITIAN}

Jenis penelitian survey analitik dengan desain cross sectional (hidayat,
2007). Metode survey analitik digunakan untuk mengukur faktor faktor umur, paritas, tingkat pendidikan, tingkat pengetahuan, persepsi ancaman, persepsi manfaat, biaya persalinan dan anjuran dengan kepuasan pemanfaatan penolong persalinan di rumah sakit grand medistra lubuk pakam. Pelaksanaan di Rumah Sakit GrandMed Lubuk Pakam, Alasan memilih tempat penelitian ini karena :

a. Adanya masalah tentang kepuasan pemanfaatan penolong persalinan.

b. Merupakan rumah sakit yang rujukan.

c. Peneliti mendapat bantuan dari petugas kesehatan setempat dalam pengambilan data, waktu dapat dipergunakan seefesien mungkin dengan jadwal yang direncanakan.

Waktu penelitian dilaksanakan oleh peneliti mulai bulan SeptemberOktober 2015.

Sampel penelitian yaitu seluruh ibu bersalin yang ada di Rumah Sakit GrandMed Lubuk Pakam sebanyak 73 orang. Pengambilan sampel menggunakan tehnik simple random sampling (Notoadmojo, 2010).

\section{HASIL}

Analisis multivariat bertujuan untuk menganalisis pengaruh beberapa variabel independen terhadap satu variabel dependen secara bersamasama. Analisis multivariat yang digunakan adalah analisis regresi logistic berganda, untuk memperoleh jawaban variabel independen yang memiliki nilai $(p \leq 0,25)$ mana di antara umur, paritas, pendidikan, pengetahuan, pemanfaatan dan biaya yang memiliki pengaruh terhadap kepuasan pemanfaatan penolong persalinan. Tahapan analisis multivariat meliputi pemilihan variabel kandidat 
multivariat, pembuatan model dan analisis interaksi.

Pemilihan variabel kandidat multivariat dilakukan dengan menggunakan analisis bivariat masingmasing variabel independen (umur, paritas, pendidikan, pengetahuan, pemanfaatan dan biaya) dengan variabel dependen (kepuasan pemanfaatan penolong persalinan). Variabel yang memiliki nilai $p$-Value < 0,25 dan mempunyai kemaknaan secara substansi dapat dijadikan variabel kandidat multivariat. Hasil analisis bivariat variabel independen dengan variabel dependen disajikan dalam tabel di bawah ini :

Tabel 1. Variabel-Variabel Kandidat Multivariat

\begin{tabular}{clc}
\hline No. & Variabel & $\boldsymbol{p}$-Value \\
\hline 1. & Umur & 0,210 \\
2. & Paritas & 0,220 \\
3. & Pendidikan & 0,077 \\
4. & Pengetahuan & 0,025 \\
5. & Pemanfaatan & 0,006 \\
6. & Biaya & 0,047 \\
\hline
\end{tabular}

Berdasarkan tabel di atas variabel umur, paritas, pendidikan, pengetahuan, pemanfaatan dan biaya memiliki nilai $p$ Value $<0,25$ sehingga keenam variabel masuk ke dalam model multivariat.

Tabel 2. Hasil Analisis Multivariat Regresi Logistik Berganda

\begin{tabular}{lccccc}
\hline \multicolumn{1}{c}{ Variabel } & Exp (B) & SE & Sig & \multicolumn{2}{c}{$95 \%$ CI } \\
\hline Umur &, 333 &, 682 &, 107 &, 087 & 1,268 \\
Paritas &, 275 &, 717 &, 071 &, 067 & 1,119 \\
Pendidikan & 2,222 &, 655 &, 223 &, 615 & 8,023 \\
Pengetahuan & 6,551 &, 881 &, 033 & 1,166 & 36,817 \\
Pemanfaatan & 3,434 &, 718 &, 086 &, 840 & 14,037 \\
Biaya & 5,191 &, 729 &, 024 & 1,244 & 21,650 \\
Constanta &, 044 & 1,084 &, 004 & & \\
\end{tabular}

Berdasarkan tabel di atas terdapat dua variabel yang memiliki nilai $p$-valued $<\alpha$ $(0,05)$ yaitu variabel pengetahuan dan biaya sehingga variabel pengetahuan dan biaya masuk ke dalam model regresi logistik berganda sedangkan variabel umur, paritas, pendidikan, pemanfaatan memiliki nilai $p$-Wald $>\alpha(0,05)$ sehingga variabel tersebut dikeluarkan dari model regresi logistik berganda. Dengan demikian model akhir regresi logistik berganda adalah model tanpa interaksi yang dapat dilihat pada tabel berikut :

Tabel 3. Model Akhir Regresi Logistik Berganda Pengaruh Faktor-Faktor Yang Berhubungan Dengan Kepuasan PemanfaatanPenolong Persalinan Pada Ibu Bersalin Di Rumah Sakit Grand Medistra Lubuk Pakam

\begin{tabular}{lccccc}
\hline Variabel & $\begin{array}{c}\text { Exp } \\
\text { (B) }\end{array}$ & SE & $\begin{array}{c}\text { p.val } \\
\text { ue }\end{array}$ & 95\%CI \\
\hline Pengetah & 5,0 &, 7 &, 022 & 1,2 & 20 \\
uan & 41 & 06 & & 62 & 1 \\
& & & & & 29 \\
Biaya & 2,7 &, 5 &, 063 &, 94 & 7, \\
& 12 & 37 & & 6 & 77 \\
& & & & & 3 \\
Constant &, 12 &, 7 &, 005 & & \\
& 2 & 55 & & & \\
\hline
\end{tabular}

Berdasarkan tabel di atas variabel pengetahuan secara signifikan mempengaruhi kepuasan dalam pemanfaatan penolong persalinan. Persamaan model regresi logistik berganda di atas adalah : Log $p$ (kepuasan pemanfaatan penolong persalinan $)=0,122+5,041$ (pengetahuan)

Hasil analisis didapatkan bahwa variabel pengetahuan memiliki pengaruh paling besar terhadap kepuasan pemanfaatan penolong persalinan yaitu dilihat dari nilai $B=$ $5,041(95 \%$ CI 1,$262 ; 20,129)$ yang berarti bahwa variabel pengetahuan memiliki pengaruh 5 kali terhadap 
Jurnal Kebidanan Kestra (JKK), e-ISSN: 2655-0822

Vol. 1 No.2 Edisi November 2018-April 2019

http://ejournal.medistra.ac.id/index.php/JKK

Received: 29 April 2019 :: Accepted: 29 April 2019 :: Published 29 April 2019

kepuasan pemanfaatan penolong persalinan.

\section{PEMBAHASAN}

Analisis hubungan beberapa variabel bebas dengan satu variabel terikat secara bersama-sama. Analisis multivariat yang digunakan untuk memperoleh jawaban variabel mana di antara umur, paritas, pendidikan, pengetahuan, ancaman, pemanfaatan, biaya, anjuran yang memiliki pengaruh terhadap kepuasan pemanfaatan penolong persalinan. Hasil analisis didapatkan bahwa variabel pendidikan memiliki pengaruh yang sangat signifikan terhadap kepuasan pemanfaatan penolong persalinan yaitu dilihat dari nilai $B=5,470 \quad(95 \% \mathrm{CI}$ 2,$708 ; 8,232$ ) yang berarti bahwa variabel pendidikan memiliki pengaruh 6 kali terhadap kepuasan pemanfaatan penolong persalinan. Sedangkan biaya memiliki nilai $B=5,199$ (95\%CI 1,041; $9,358)$ yang berarti biaya memiliki pengaruh 5 kali terhadap kepuasan pemanfaatan penolong persalinan.

Pendidikan memang penting karena merupakan dasar dari mengertinya seseorang dalam hal menerima informasi. Informasi dapat lebih muda diterima dan diadopsi pada orang yang mempunyai pendidikan lebih tinggi daripada pendidikan rendah. Umumnya masyarakat menyadari pentingnya pendidikan untuk bekal kehidupan di masa depan, dengan pendidikan mereka bisa baca, tulis dan berhitung sehingga tidak dibodohin orang lain. Ibu bersalin dan bayinya, khususnya dalam masa perinatal memiliki risiko terhadap kematian atau kelangsungan hidupnya. Oleh karena itu dalam persalinan, seorang ibu hendaknya pada saat persalinan ditolong dokter dan bidan yang terampil dan professional yang dalam pencegahan infeksi dan komplikasi.
Petugas kesehatan juga harus mempunyai kemampuan untuk mendeteksi kegawatdaruratan pada ibu bersalin yang terjadi serta dapat melaksanakan penanganan jika terjadi komplikasi pada ibu bersalin tersebut, sehingga AKI dan AKB dapat diatasi.

Berdasarkan hasil analisis diketahui bahwa $34,2 \%$ responden mengatakan puas dalam memanfaatkan penolong persalinan untuk membantu kelahiran anaknya, peneliti juga melihat masih ada $42,5 \%$ responden menyatakan kurang puas dalam memanfaatkan penolong persalinan (dokter atau bidan), menurut asumsi peneliti hal ini mungkin di sebabkan karena beberapa faktor responden yang datang kerumah sakit pada saat persalinan atau bebarapa faktor lain yang ada di Rumah Sakit GrandMed Lubuk Pakam.

\section{KESIMPULAN}

Pendidikan memiliki pengaruh paling besar terhadap kepuasan pemanfaatan penolong persalinan yaitu dilihat dari nilai $B=5,470 \quad(95 \% \mathrm{CI}$ 2,$708 ; 8,232$ ) yang berarti bahwa variabel pendidikan memiliki pengaruh 6 kali terhadap kepuasan pemanfaatan penolong persalinan. Sedangkan biaya memiliki nilai $B=5,199$ (95\%CI 1,041 ; 9,358) yang berarti biaya memiliki pengaruh 5 kali terhadap kepuasan pemanfaatan penolong persalinan.

\section{DAFTAR PUSTAKA}

Adisasmita Wiku, Ph.D. 2008. System kesehatan , PT. Rajagrafindo Persada

Badan Pusat Statistik Provinsi Sulawesi Selatan. Indikator Kesejahteraan Rakyat Sulawesi Selatan tahun 2004. Makassar : BPS Provinsi Sulawesi Selatan. 2004.

Bakosurtanal, Sistem Informasi Spasial Nasional (SISN). Internet, 
http://202.155.86.41/kpk/pp10/p p10.htm. Diakses tanggal 13 November 2011.

Bangsu, Tamrin. Dukun Bayi Sebagai Pilihan Utama Tenaga Penolong Persalinan. Jurnal Penelitian UNIB, Vol. VII, No. 2, Juli 2001, Hal. 104-109. Diakses tanggal April 2012.

Benny N Joewono, 2012. Internet regional.kompas.com//Angka.Kem atian.Ibu.2012 diakses 31 Jan 2012

Biro Pusat Statistik, Survei Kesehatan Rumah Tangga. Jakarta: Biro Pusat Statistik, 1995.

Dinas Kesehatan Kabupaten Asahan. Profil Kesehatan Kabupaten Asahan 2010

Depkes RI, 2004. Asuhan Persalinan Normal, Jakarta. 2005. Rencana Strategis Departemen Kesehatan 20052009, Jakarta. , 2007, Setiap jam 2 orang Ibu Bersalin Meninggal Dunia. Internet http://www.depkes.go.id. Diakses tanggal 21 Februari 2007.

Juliwanto, 2008. Faktor-faktor yang mempengaruhi keputusan memilih penolong persalinan pada ibu hamil di kecamatan babul rahmah kabupaten aceh tenggara tahun 2008. Tesis Pasca Sarjana FKM Universitas Sumatera Utara.

Jakir dan Amiruddin, 2007. Faktor yang Berhubungan Dengan Pemilihan Tenaga Penolong Persalinan oleh Ibu Bersalin di Wilayah Kerja Puskesmas Borong Kompleks Kabupaten Sinjai Tahun 2006. www.wordpress.com. Diakses tanggal 18 April 2010

Kandra Wilko, 2011 kebidanan, kesehatan ibu dan anak di Saturday, diakses tanggal 12 Desember 2011
Maas, Linda T. Kesehatan Ibu dan Anak : Persepsi Budaya dan Dampak Kesehatannya. USU Digital Library. 2004. Diakses tanggal 21 September 2006.

Manalu, Hotma Liner, 2007. Pengaruh Karakteristik Ibu Hamil Terhadap Pemanfaatan Penolong Persalinan di Wilayah Kerja Puskesmas Sunggal Kecamatan Medan Sunggal Tahun 2007, Skripsi FKM USU, Medan.

Manuaba I.B. G. 2001. Ilmu Kebidanan, Penyakit Kandungan dan KB untuk Pendidikan Bidan. EGC. Jakarta.

Maria, Ulfa, 2004. Penguatan Hak Kesehatan Reproduksi dan Komunikasi Islam, SKRT, www.tatayat.or.id : Sabtu 28 September 2011

Moleong, L.J. 2000. Metodologi Penelitian Kualitatif. Cetakan Keenam belas. PT. Remaja Rosdakarya. Bandung.

Mulidah, 2002, Penyulit Dalam Kehamilan, Persalinan dan Nifas, EGC, Jakarta

Nasution, Syamsul Arifin. Gambar Penanganan Kasus Kedaruratan Obstetri di RSU Tanjung Pura Kab. Langkat dan RSU Kisaran Kab. Asahan. USU Digital Library. 2003. Diakses tanggal 1 Februari 2007.

Notoatmodjo. 2003. Pengantar pendidikan Kesehatan dan Ilmu Perilaku. Rineka Cipta. Jakarta. 2003. Ilmu Kesehatan Masyarakat, Prinsip-prinsip Dasar. Jakarta :Rineka Cipta. Jakarta

, $2005 . \quad$ Metodologi Penelitian Kesehatan. Jakarta : Rineka Cipta. Jakarta

Nurdin, Adnil Edwin, 2011. Tumbuh Kembang Perilaku Manusia, ECG : Jakarta 
Prawirohardjo, Sarwono, 2009. Ilmu Kebidanan, PT. Bina Purtaka Sarwono Prawirohardjo: Jakarta

Riyanto, A., 2009. Pengolahan Dan Analisis Data Kesehatan (Dilengkapi Uji Validitas dan Realibilitas serta Aplikasi Program SPSS), Yogyakarta : JazameDia.

Rodhiyah, dkk. 1999. Peran Suami dan Anggota Keluarga Lain dalam Keputusan Perujukan Persalinan. Laporan Penelitian. Pusat Penelitian Kesehatan. Lemlit Undip. Semarang

Roeshandi, 2004, Gangguan dan Penyulit Pada Masa Kehamilan, diakses dari http://www.google.co.id. 4 Januari 2011.

Santoso, Slamet I. Pendidikan di Indonesia Dari Masa ke Masa. Jakarta : CV Haji Masagung. 1987. Suprapto, Agus. Determinan Sosial Ekonomi Pertolongan Persalinan. Internet, http://digilib.litbang.depkes.go.id. Diakses tanggal 26 September 2006.

SDKI. 2003. Survei Demografi dan Kesehatan Indonesia. Jakarta.
Sukarma, Indikator Kematian Ibu, diambil pada tanggal 26 Juli 2010; http://www.datastatistikindonesia.com

Suprapto, Agus. Pola Pertolongan Persalinan 5 Tahun Terakhir Hubungannya dengan Faktor Sosial Ekonomi Di Indonesia. Internet, http://digilib.litbang.depkes.go.id. Diakses tanggal 26 September 2006.

1999. Analisis Hubungan Faktor Sosial Ekonomi Dengan Pola Pertolongan Persalinan 5 Tahun Terakhir Dengan Faktor Sosial Ekonomi di Indonesia, Analisis Data Susenas, 2001, Jakarta

Yasril, Kasjono, H.S., 2009. Analisis Multivariat Untuk Penelitian Kesehatan, Jogjakarta : Mitra Cendekia Press

Yustina, Ida. Upaya Strategis Menurunkan AKI dan AKB. Jurnal Wawasan, Oktober 2007, Volume 13, Nomor 2 